Aleksandra Janowska*

\title{
KOMPARATYSTYCZNA ANALIZA UTWORU REIGEN ARTHURA SCHNITZLERA ORAZ JEGO TEUMACZENIA PT. TANIEC MIEOŚCI AUTORSTWA MARIANA ZBARASKIEGO
}

\section{Wprowadzenie}

Utwór Reigen napisany przez Austriaka żydowskiego pochodzenia Arthura Schnitzlera jest niezwykle istotną publikacją, która ukazała się w epoce wiedeńskiego modernizmu. Przyczyną jej popularności jest m.in. obecność nowego, jak na tamte czasy, postrzegania seksualności człowieka oraz liczne nawiązania do teorii psychoanalizy Zygmunta Freuda, która była w tym okresie rozpowszechniona i mimo licznej grupy przeciwników miała również swoich zwolenników.

Czas pracy nad utworem był krótki - wynosił trzy miesiące na przełomie lat 1896/1897. Warto zaznaczyć, że Reigen z początku ukazało się w dwustu egzemplarzach jako druk prywatny, a dopiero w roku 1903 dzieło opublikowano w ilości 14000 egzemplarzy. Po opublikowaniu dramatu ukazywały się jego recenzje. Autorem jednej z nich był Alfred Kerr - krytyk teatralny oraz eseista - który zwrócił szczególną uwagę na to, iż czytając Reigen, czytelnik ma wrażenie, że znajduje się w zamkniętym kręgu (Schnitzler 2014: 146). Dodatkowo ważnym aspektem było według niego to, że w każdej scenie występuje mężczyzna i kobieta. Nigdy podczas czytania dramatu nie mamy do czynienia z bohaterami tej samej płci ${ }^{1}$.

W roku 1921 ukazało się jedno z pierwszych tłumaczeń dramatu na język polski. Jego autorem jest Marian Zbaraski, który przełożył dzieło, nadając mu tytuł Taniec miłości. Dzięki temu przekładowi polski czytelnik nie znający języka niemieckiego mógł poznać treść utworu kilkanaście lat po jego opublikowaniu

\footnotetext{
Mgr Aleksandra Janowska, Uniwersytet Łódzki.

1 Podobna recenzja, również autorstwa Kerra, ukazała się jeszcze przed publikacją dramatu, w roku 1900 na bazie druku prywatnego.
} 
za granicą. Przekład ten jest ciekawą pozycją literacką ze względu na zaproponowane rozwiązania translatoryczne i niejednokrotnie odbiegającą od oryginału interpretację tłumacza.

Komparatystyczna analiza oryginału dzieła oraz jego przekładu jest ściśle związana $\mathrm{z}$ tematem monografii. Migracja zaprezentowana $\mathrm{w}$ artykule jest w szczególności ukazana w samym procesie tłumaczenia utworu - w podobieństwach i różnicach między dwiema wersjami tekstu.

Celem tego artykułu jest przybliżenie czytelnikowi różnic między oryginałem a przekładem, wynikających z modyfikacji zastosowanych przez tłumacza. Dzięki temu zestawieniu czytelnik, który nie włada perfekcyjnie językiem niemieckim, będzie miał możliwość przeprowadzenia pogłębionej analizy całego tekstu oraz poszczególnych kwestii w nim zawartych. Czytelnik nie pominie przy tym istotnych elementów albo fraz, które w tłumaczeniu albo nie występują, albo zostały zmodyfikowane. Pytanie, które należy zadać przy przeprowadzeniu komparatystycznej analizy obu tekstów, brzmi następująco: W jakim stopniu - i czy w ogóle - przekład autorstwa Mariana Zbaraskiego oddaje kwintesencję tekstu oryginalnego? Czy w przypadku, gdy przekład znacznie różni się od wersji pierwotnej, warto po niego sięgać?

Odpowiedzi na te pytania są szczególnie istotne, ponieważ dzięki nim możliwa jest obiektywna ocena jakości tłumaczenia oraz podjęcie decyzji, czy po dany przekład warto sięgnąć $\mathrm{w}$ celu zapoznania się $\mathrm{z}$ utworem, który oryginalnie nie został napisany w języku polskim.

\section{Krótka charakterystyka utworu}

Reigen jest dramatem składającym się z dziesięciu scen. W każdej z nich postaciami mówiącymi są przedstawiciele różnych klas społecznych. Istotne jest, że każda z nich tworzy w dramacie własną historię. W utworze nie można wyróżnić ani głównego bohatera, ani bohaterów pobocznych. Rozkład poszczególnych postaci, a tym samym dramatu, wygląda następująco:

I. Dziewka i Żołnierz

II. Żołnierz i Pokojówka

III. Pokojówka i Panicz

IV. Panicz i Młoda Mężatka

V. Młoda Mężatka i Małżonek

VI. Małżonek i Słodka Dziewczyna

VII. Słodka Dziewczyna i Poeta

VIII. Poeta i Aktorka

IX. Aktorka i Hrabia

X. Hrabia i Dziewka

W każdej ze scen postacie prowadzą dialog. Szczególnym elementem wyróżniającym ten utwór jest fakt, że mimo reprezentowania różnych klas społecznych, 
między postaciami dochodzi do aktu seksualnego. Jego występowanie jest zasugerowane w niekonwencjonalny sposób - za pomocą ciągu myślników tworzących linię. To właśnie ona ma symbolizować zbliżenie między bohaterami. Każda postać pojawia się w utworze dwa razy, a mianowicie w każdych dwóch następujących po sobie dialogach. Wyjątkiem jest Dziewka, która pojawia się w scenie pierwszej oraz dziesiątej. Zaprezentowana struktura kręgu w tym tekście nie jest przypadkowa. Bez wątpienia zamiarem Schnitzlera było zwrócenie uwagi na to, że historia zawsze zatacza koło, co również jest ściśle związane z tytułem utworu, sugerującym pewnego rodzaju powtarzalność.

Tematyka erotyczna oraz obecność aktów seksualnych między postaciami niewątpliwie sugeruje inspirację Schnitzlera Freudowską psychoanalizą, jednak Reigen nie zostało napisane pod jej wpływem². Można to wywnioskować m.in. $\mathrm{z}$ korespondencji prowadzonej między tymi dwoma lekarzami. W swoich listach z roku 1906 oraz 1922 psychoanalityk wyraża głębokie zdumienie co do tego, że Schnitzler był w stanie opisać coś, do czego sam Freud musiał dochodzić latami w swoich badaniach (Wunberg 2018: 651-653).

Premiera fragmentu utworu na deskach teatru miała miejsce w Berlinie i Monachium w roku 1903 oraz w Budapeszcie i w Rosji w roku 1910. Wszystkie te inscenizacje odniosły sukces. Cały utwór zaprezentowano również w Berlinie w Kleines Schauspielhaus w roku 1920. Wystawienie całego dramatu wywołało oburzenie wśród społeczeństwa oraz władzy. Prezentowanie popędów oraz otwarte mówienie o seksualności jako o wartości rządzącej ludzkim umysłem nie było jeszcze dla wszystkich tematem tak powszechnym. Po premierze całego utworu zakazano publikacji Reigen, a jego ponowna prezentacja była możliwa dopiero w roku 1982. Dodatkowo wytoczono proces Arthurowi Schnitzlerowi. Przed sądem wywiązał się wówczas dający dużo do myślenia dialog:

PRZEWODNICZĄCY: Podpisał się Pan pod protestem przed, czy po obejrzeniu spektaklu?

SWIADEK: Protest podpisałem przed obejrzeniem spektaklu.

PRZEWODNICZĄCY: Skąd w takim razie znał Pan treść utworu?

ŚWIADEK: Ze słyszenia.

PRZEWODNICZĄCY: Czyli nie dzięki własnej lekturze?

ŚWIADEK: $\mathrm{Nie}^{3}$.

Z wyżej przytoczonej rozmowy można wysnuć wniosek, że nie każdy zarzut w kierunku Schnitzlera był uzasadniony. Osobista refleksja po przeczytaniu dramatu lub obejrzeniu go na scenie jest niewspólmierna ze znajomością tekstu „ze słyszenia”.

2 Zarówno Arthur Schnitzler, jak i Zygmunt Freud byli z wykształcenia lekarzami. W kręgu ich zainteresowań znajdowały się ludzka psychika i neurologia.

${ }^{3}$ Schnitzler, Arthur (2014), Reigen. Text und Kontext, tłum. [A. J.]. Stuttgart, s. 152. 


\section{Thumaczenie tytułu}

Reigen. Zehn Dialoge to pełny tytuł dramatu, który w języku polskim brzmi Taniec miłości. Wstępnie to tłumaczenie tytułu wydaje się być trafne, ponieważ $\mathrm{w}$ dużym stopniu związane jest $\mathrm{z}$ treścią utworu. Pod metaforą tańca miłości kryje się forma utworu. Dziesięć połączonych ze sobą dialogów tworzy krąg, w którym pierwsza osoba „tańczy” z drugą, druga z trzecią, trzecia z czwartą i tak do końca dramatu. Tę formę można określić mianem „odbijanego tańca”.

Krąg zamyka Dziewka tańcząca z Hrabią, ponieważ pojawia się ona - jak już zostało wspomniane - zarówno w pierwszej, jak i ostatniej scenie dramatu. W ostatniej scenie zauważalne jest, że kolejną postacią, która pojawiłaby się po Dziewce, jest Pokojówka, o czym świadczą słowa:

\section{POKOJÓWKA.}

Dzień dobry.

HRABIA.

Ach tak... dzień dobry... dzień dobry. (Schnitzler 1921: 139).

Ten fragment ostatniej sceny jest dowodem na to, że postacie tańczą w kręgu, który dzięki przetłumaczeniu tytułu Reigen jako Taniec miłości, został uchwycony. Ta kwestia jest dowodem na to, że tłumacz dostrzegł bardzo ważny aspekt utworu, który postanowił ująć już w tytule. Na tę kwestię zwraca również uwagę krytyk teatralny i dramaturg, Piotr Gruszczyński:

U Schnitzlera nie ma sprawiedliwych. Wszyscy bohaterowie są siebie warci. Kłamią i zdradzają bez ustanku. Zdradzają przede wszystkim siebie samych i swoje idealne wyobrażenia, dopiero potem swoich ewentualnych życiowych partnerów. Każdy występuje w dwóch scenach, które często przystają do siebie tak jak negatyw i pozytyw. W jednej scenie zdradzający zdradza, w następnej jest zdradzany, w jednej uwodzi, w kolejnej zostaje uwiedziony, w jednej jest agresywny i niezdobyty, w drugiej lagodny i naiwny. Tak toczy się gra, o tyle okrutna, że niepokojąco bliska codzienności mieszkańców ziemskiego Babilonu. Gra pozbawiona nadzwyczajnych uniesień i niezwykłych odczuć. Codzienna i nieprzyjemna, choć oparta na przyjemności. (Gruszczyński 1997: 13).

Nie jest możliwe, aby jednoznacznie stwierdzić, czy tłumaczenie tytułu zaproponowane przez Mariana Zbaraskiego jest najlepszym rozwiązaniem. Reigen to w języku polskim korowód, a według słownika PWN jest to „długi szereg osób posuwających się jedna za drugą"4. Korowód niezaprzeczalnie kojarzy się również z szeregiem osób idących za trumną na pogrzebie. Również ta kwestia jest związana bezpośrednio z utworem.

${ }^{4}$ https://sjp.pwn.pl/sjp/korowod;2474153.html [Dostęp: 15.06.2020]. 
W Reigen dużą rolę w treści dzieła odgrywają Eros i Tanatos, czyli bogowie Miłość i Śmierć, wywodzący się z filozofii starożytnej. Postacie nie raz podkreślają w swych wypowiedziach, jak ważne są dla nich popędy i spełnienie seksualne oraz korzystanie z życia, dopóki ono trwa. Przykładem to potwierdzającym jest między innymi wymiana zdań pomiędzy Dziewką a Żołnierzem: „Pójdź! Kto tam wie czy jutro będziemy jeszcze żyli” (Schnitzler 1921: 139). Czytając te słowa, czytelnik może odnieść wrażenie, że dla bohaterów nie mają znaczenia żadne emocje poza mechanicznym popędem seksualnym. Tego rodzaju wewnętrzne wyniszczenie pokazuje, że są oni zagubieni oraz ich sfera psychiczna ulega coraz większej degradacji. Ten aspekt może wskazywać na to, że nie mamy do czynienia z miłosnym tańcem, lecz z tańcem śmierci, tzw. danse macabre. Ten alegoryczny taniec ma na celu uświadomienie, że w obliczu śmierci każdy jest równy, niezależnie od reprezentowanej klasy społecznej i to właśnie ona pełni funkcję weryfikatora naszych ziemskich dokonań.

Mimo tych sprzeczności tłumaczenie tytułu Mariana Zbaraskiego może być pomocne przy zrozumieniu i analizie utworu. Dodatkowo może ono zaciekawić czytelnika nawet tuż przed rozpoczęciem lektury.

\section{Analiza językowa tłumaczenia treści utworu oraz jego poprawności}

Analiza jakości przekładu utworu względem oryginału będzie stanowiła ważny element, pomocny podczas zapoznawania się z dramatem $\mathrm{w}$ języku polskim. Liczne różnice oraz niekonsekwencja obecne w tłumaczeniu mogą zaburzać czytelnikowi zrozumienie treści utworu. Chociaż sam przekład naprowadza na wysnucie wniosków oraz przemyśleń, to jednak niektóre zabiegi translatorskie stanowczo utrudniają dogłębną analizę tekstu oraz jego zrozumienie. W niniejszym artykule przytoczę kilka przykładów, które moim zdaniem są niezwykle istotne zarówno dla osób interesujących się modernizmem jako epoką literacką i kulturową, jak i dla wielbicieli twórczości Arthura Schnitzlera oraz Freudowskiej psychoanalizy.

Pierwszym niezwykle istotnym aspektem różniącym oryginał od tłumaczeniu utworu jest fraza „Kocham cię”. Umieszczenie tego sformulowania w przekładzie jest sprzeczne $\mathrm{z}$ oryginałem, $\mathrm{w}$ którym te słowa nie padają $\mathrm{z}$ ust żadnego bohatera. Chociaż w scenie piątej (Młoda Mężatka i Mąż) małżonkowie zwracają się do siebie czule, z ust żadnego z nich nie pada „Ich liebe dich”, czyli „Kocham cię". Ich uczucie w oryginale jest wyrażone za pomocą innych słów, mianowicie: „Verliebt bin ich in dich!” (Schnitzler 2014: 43), które w języku polskim znaczą jestem w tobie zakochany, czy „Ich bin glücklich, daß ich dich gefunden habe” (Schnitzler 2014: 45), czyli jestem szczęśliwy, że cię znalazłem. Mimo że te sformułowania można uznać za dążące do miłosnego wyznania, to tak naprawdę się 
nim nie stają. Marian Zbaraski nie zachował tej konsekwencji w swoim przekładzie. Zamiast: „Nichts mein Kind. Verliebt bin ich in dich! Das weißt du ja” (Schnitzler 2014: 43) posłużył się słowami: „Nic moje dziecko. Kocham cię. Wiesz przecież o tem" (Schnitzler 1921: 50). Jest to znacząca różnica, która przyczynia się do przekłamania w treści utworu. Brak obecności w oryginale frazy „Kocham Cię” był u Schnitzlera bardzo znaczący. Celem było pokazanie roli popędów rządzących człowiekiem. Należy zwrócić uwagę na to, że nie zawsze są one zależne od czwartego czy piątego poziomu rozwoju osobowości zaliczanych do Teorii Dezintegracji Pozytywnej (TDP) według prof. Kazimierza Dąbrowskiego $^{5}$. W tym utworze zachowania postaci można bez zastanowienia przyporządkować zarówno do pierwszego poziomu (miłość popędowa/seksualna), jak i do drugiego (miłość erotyczna, zmysłowa, sensualna), który łączy się z zasadą przyjemności według Freuda.

Kolejnymi przykładami ukazującymi dysonans między oryginałem a thumaczeniem są słowa, które padają w dialogu trzecim między Paniczem i Pokojówką. W tej scenie Panicz zaczyna uwodzić Pokojówkę, dzięki czemu ich rozmowa prowadzi do gry wstępnej, która w oryginale jest wyrażona w o wiele bardziej zmysłowy sposób: „,schöne weiße Haut”, ,küßt sie auf die Brust”, ,Weil Sie so seufzen! Warum seufzen Sie denn?” (Schnitzler 2014: 22). Tłumacząc te zwroty kolejno na język polski będą one oznaczały: piękna biała skóra, całuje jej biust/piersi, Pani tak wzdycha! Dlaczego Pani tak wzdycha? Zamiast zachowania konsekwencji w dialogach tłumacz proponuje takie rozwiązanie translatorskie: „Marynia ma ładną białą cerę”, „całuje ją w piersi”, „Bo Marynia tak wzdycha! Czego Marynia tak wzdycha?" (Schnitzler 1921: 25-26). Poprzez wprowadzenie imienia postaci do utworu tłumacz eliminuje początkową anonimowość Pokojówki oraz tym samym przyczynia się do powstania kolejnej, istotnej różnicy między swoim przekładem a oryginałem. Kwintesencją utworu było m.in. zachowanie anonimowości między postaciami i zamiast nadania im konkretnych imion posłużenie się nazwami warstw społecznych. Miało to na celu jeszcze większe uświadomienie czytelnika, że dla bohaterów nie odgrywało jakiejkolwiek roli to, kim są i czym się zajmują, ponieważ najwyższą wartością kierującą ich umysłami było zaspokojenie popędu seksualnego.

Podobny aspekt wprowadzający dysonans między dialogami pojawia się w scenie drugiej. W porównaniu do innych błędów jest on jednak na tyle mało ingerujący $\mathrm{w}$ ogólne rozumienie utworu, że na pierwszy rzut oka może być niemal niezauważalny. Sugerując się pozostałymi zmianami wprowadzonymi przez tłumacza, warto jednak wskazać tę różnicę, ponieważ przyczynia się do przekłamania treści, nie wprowadzając do niej niczego podnoszącego rangę przekładu. Scena, o której mowa, rozgrywa się między Żołnierzem

5 https://dezintegracja.pl/milosc-na-roznych-poziomach-rozwoju-osobowosci-w edlug-teorii-dezintegracji-pozytywnej-pl/ [Dostęp: 16.06.2020]. 
a Pokojówką. Pomiędzy pierwszym a drugim aktem seksualnym w tym dialogu obie postacie prowadzą krótką wymianę zdań, w której (w oryginale) Pokojówka zwraca uwagę, że nie jest w stanie dostrzec twarzy Żołnierza, który w odpowiedzi podkreśla, że twarz tak naprawdę nic nie znaczy: „... Ich kann dein G'sicht gar nicht sehn”, „Ah was - G'sicht ...” (Schnitzler 2014: 15). Dzięki temu dialogowi można zwrócić szczególną uwagę na to, jak ważna dla bohaterki jest subtelność, spojrzenie na twarz drugiej osoby podczas tak intymnego przeżycia. Zbaraski zdecydował się na nieuzasadnione wprowadzenie teoretycznie podobnej wymiany zdań między Pokojówką a Żołnierzem: „... Nie śmiem ci nawet w oczy patrzeć”, przy czym odpowiedź Żolnierza brzmi następująco: „E, co tam oczy” (Schnitzler 1921: 17). Oprócz wprowadzonej w tlumaczeniu zmiany części ciała, pojawia się przypuszczenie, że Pokojówka tak naprawdę widzi twarz kochanka, jednak ma obawę, bądź wstydzi się spojrzeć mu w oczy. Czytając samo tłumaczenie można domniemywać, że w pewien sposób onieśmiela ją wyższy stan społeczny bohatera. $\mathrm{W}$ oryginale takie przypuszczenie nie byłoby uzasadnione. Zmienia ono wyjściowy kontekst i wyżej przytoczoną interpretację tego fragmentu, a tym samym przyczynia się do kolejnego zakłamania wyjściowej treści utworu.

Ostatni przykład, który przytoczę, jest zarówno podobieństwem, jak i różnicą między utworem oryginalnym a jego tłumaczeniem. Dotyczy on niekonsekwencji tłumacza względem zaproponowanego przez siebie przełożenia na język polski nazewnictwa postaci występujących w dramacie. Przed rozpoczęciem lektury czytelnik ma możliwość zapoznania się z postaciami, które będą występować w utworze. Ze spisu bohaterów umieszczonego w przekładzie Zbaraskiego dowiemy się, że jest to m.in. Młoda Mężatka oraz Małżonek. $\mathrm{W}$ momencie, kiedy podczas czytania dramatu zbliżamy się do tego dialogu, możemy odnieść wrażenie, że zaproponowane nazewnictwo bohaterów jest nie do końca poprawne. W scenie piątej rozmawiają ze sobą Młoda Mężatka oraz Mąż. Mimo że Małżonek oraz Mąż są tymi samymi osobami, czyli przedstawicielami płci męskiej będącymi w związku małżeńskim, to czytelnik może dostrzec dysonans między tym nazewnictwem. Chociaż obecnie tłumacze mogliby stwierdzić, że należy zachować konsekwencję względem imion czy nazw postaci, trzeba posłużyć się oryginałem, w celu zweryfikowania zasadności takiego rozwiązania translatorskiego. W dialogu piątym u Schnitzlera także zastosowano ten zabieg. Chociaż w spisie bohaterów widnieje „der Ehegatte”, to w tytule dialogu piątego autor również posłużył się synonimem „der Ehemann", który zaś w treści właściwej rozmowy zastąpił kolejnym odpowiednikiem „der Gatte” (Schnitzler 2014: 43). Różne określenia tej samej postaci zarówno w oryginale, jak i w przekładzie nie utrudniają bowiem zrozumienia tekstu oraz przekazu. Należy więc stwierdzić, że tłumacz w dużym stopniu odwzorował tę kwestię w swoim przekładzie. 


\section{Wnioski}

Niezaprzeczalnym jest, że różnica między Schnitzlerowskim oryginałem a przekładem Zbaraskiego jest znacząca. Osoby władające swobodnie językiem niemieckim mogłyby stwierdzić, że w tłumaczeniu obecne są przekłamania, które niebagatelnie utrudniają bardzo wnikliwą analizę dramatu. Mimo ogólnego zachowania sensu utworu widoczny jest ten dysonans. Zaproponowane przez tłumacza rozwiązania językowe często przyczyniają się do zmian w treści dzieła. Chcąc poznać ogólną problematykę oraz historie postaci w Reigen, można to zrobić przy pomocy omawianego w tym artykule tłumaczenia. Należy jednak zachować pewien dystans i starać się zapoznać z oryginalnym tekstem, aby móc wysnuć osobiste wnioski dotyczące utworu oraz stwierdzić, czy twórczość tego autora jest w odczuciu konkretnego czytelnika interesująca. Myślę, że ten przekład będzie szczególnie pomocny osobom dopiero uczącym się języka niemieckiego, jednak mimo wszystko zalecanym jest, aby zapoznać się z Reigen w jego oryginalnej formie.

\section{Bibliografia}

Gruszczyński, Piotr (1997), Cały urok Schnitzlera. W: „Tygodnik Powszechny” nr 28, s. 13.

Schnitzler, Arthur (1921), Taniec mitości. Lwów.

Schnitzler, Arthur (2014), Reigen. Text und Kontext. Stuttgart.

Wunberg, Gotthart (2018), Die Wiener Moderne. Literatur, Kunst und Musik zwischen 1890 und 1910. Stuttgart.

\section{Źródła internetowe}

https://sjp.pwn.pl/sjp/korowod;2474153.html [Dostęp: 15.06.2020].

Wolny, Witold, Miłość na różnych poziomach rozwoju osobowości według Teorii Dezintegracji Pozytywnej, https://dezintegracja.pl/milosc-na-roznych-poziomach-rozwo ju-osobowosci-wedlug-teorii-dezintegracji-pozytywnej-pl/ [Dostęp: 16.06.2020]. 


\title{
Aleksandra Janowska \\ Comparative anylisis of "Reigen" by Arthur Schnitzler and its (Polish) translation ”Taniec miłości” by Marian Zbarski
}

\begin{abstract}
The novel Reigen (La Ronde) written by Arthur Schnitzler - an Austrian author of Jewish origin, is an extremely crucial publication. It was written in the era of so-called Viennese modernism. The reason for its popularity is, among others, the presence of a new perception of human sexuality and numerous references to the Sigmund Freud's theory of psychoanalysis; which, at that time, was widespread and had not only its supporters, but also a large group of opponents.

In 1921, one of the first Polish translations of the novel appeared. Its author - Marian Zbarski, translated the title into Taniec Miłości (The Dance of Love.) Arguably, the work makes for an interesting literary position, due to the solutions used for text translation and the translator's interpretation which, often enough, deviates from the original text.

The purpose of this essay is to bring the reader closer to the differences between the original and the translated texts. Those dissimilarities occur mostly because of the modifications used for the translation. When conducting a comparative analysis of both texts, it is necessary to ask a question of whether and to what extent the translation by Marian Zbaraski reflects the quintessence of the original work. One may ask if the translated text is worth reading, in case it differs significantly from the original version.

The answers to these questions are particularly important, because they make impartial assessment of the quality of the translation assessable. It helps the reader decide whether the translated novel is worth reading, especially if one wants to get acquainted with the work, that was not originally written in Polish.
\end{abstract}

Keywords: Arthur Schnitzler, Marian Zbaraski, Reigen translation, Vienna Modernism, psychoanalysis, sexual desire.

Słowa kluczowe: Arthur Schnitzler, Marian Zbaraski, Reigen, Taniec miłości, Wiedeński Modernizm, psychoanaliza. 